\title{
PA-1-1＼cjkstart当科における顎矯正手術の臨床統計的検討
}

${ }^{1}$ 日本大学松戸歯学部 顎咬合形成外科学, ${ }^{2}$ 日本大学松戸歯学部 総合口腔医学 (顎顔面矯正学), ${ }^{3}$ アイアイ矯正歯科, ${ }^{4}$ 日本大学松戸 歯学部 歯科矯正学

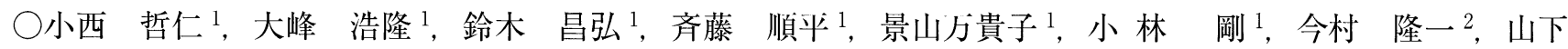
利明 ${ }^{3}$, 葛西 一貴 4

【目的】近年における顎変形症患者に対する外科的矯正治療は，進歩と改良によって普及し矯正・口腔外科分 野において重要な部分を占めている。今回，当科の外科的矯正の現状を把握するために，顎矯正手術例に対し て臨床統計的検討を行ったので報告する。【対象・方法】1983 年 1 月 2005 年 12 月までの 23 年間に当科（旧・ 顎咬合形成外科，現・顎咬合形成外科）に紹介・診断され顎矯正手術を施行された患者 685 例を対象とした。 患者数・性別・年齢・術式別症例数・固定法について後ろ向き調査を行い顎矯正手術の経年変化について比 較・検討を行ったので報告する。【結果】年間手術件数は平均 30 例（中央值 26）過去 5 年平均は, 61 例（中 央值 60）である。症例の性別は男 202 人, 女 483 人, 男女比 $1: 2.4$ と女性が多かった。手術時年齢は 14 歳〜 53 歳で平均 23.4 歳（中央值 22 歳）であった。過去 5 年では 30 歳代の顎矯手術割合の増加傾向が認められた。 診断別症例数では下顎前突単独例が最も多く，次いで下顎前突に開咬や偏位を伴ったものとなっており，下顎 前突に類似する症例は全体の $77 \%$ であた。手術の術式は，下顎骨矢状分割術（SSRO）の症例が多く542 例, 次いで上下顎移動術 83 例, オトガイ形成術 30 例で以下, 上顎移動術・IVRO・上顎歯槽骨骨きりの順であっ た。骨片固定法は, 平成 4 年まではワイヤーによる固定, 平成 5 年〜チタンミニプレートによる固定, 平成 11 年〜吸収性プレートの認可により使用開始。近年まで徐々に使用回数が増加し，近年（過去 5 年）の使用 割合は $52 \%$ であった。【結論】固定材料は, 吸収性プレート認可採用の初年度より約半数の症例に使用され, 以後ほぼ一定数に維持されている。治療対象の年歯割合の高齢傾向が認められるため今後多種多様の対応が必 要だと考えられる。

\section{PA-1-2 日本歯科大学附属病院顎変形症診療センターの集学的治療と今後の課題}

\section{${ }^{1}$ 日本歯科大学附属病院 顎変形症診療センター}

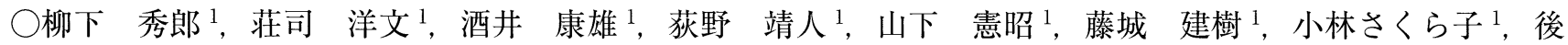
藤 尚昭 ${ }^{1}$, 小林隆太郎 ${ }^{1}$

【目的】顎変形症の治療においては口腔外科, 矯正歯科などの複数の科との緊密な共同治療や看護職, 栄養士 （NST を含む）さらには院外施設との連携体制も重要である。そこで今回，当院で今まで行われてきた顎変形 症に対するチーム医療の推移と現在の集学的治療システムについて報告し, 当センターの課題点, 今後の顎変 形症治療の方向性を検討した。【方法】本院においては 1978 年に外科的矯正治療が始まった。1995 年 4 月に は顎変形症プロジェクトチームが発足。2001 年 1 月に顎変形症診療センターが設立された。今回はチーム医 療が始まった 1994 年 4 月から 2006 年 12 月までの 11 年間において顎変形症と診断された初診患者数，手術件 数を年度別にし，その期間の当院でのシステムの変化と合わせ検討した。【成績】2001 年に大学機構改革が開 始され，臨床部門と教育部門の二元化が行われた。2005 年 4 月 1 日から 7 月 18 日の間，病院改築のため，約 4 か月の病棟閉鎖が行われ。また，日本医療機能評価機構受診に適合することを目的にその間，今後の外科的 矯正治療の指針について検討を行い，実施の段階となった。病棟閉鎖に伴なう手術件数の変化は 2004 年 143 例, 2005 年 89 例, 2006 年 91 例であった。【まとめ】 今後, 当センターにおいてクリティカルパスの導入を図 り, 矯正歯科, 医師, NST チームとの連携を一段と強めると同時に矯正歯科開業医との医療連携が重要であ ることが考えられた。 


\section{PA-1-3 NTT 西日本大阪病院歯科口肬外科における外科矯正手術症例の臨床統計的観察}

${ }^{1} \mathrm{NTT}$ 西日本大阪病院 歯科口腔外科, ${ }^{2}$ 公立学校共済近畿中央病院 口腔外科

○増田 智丈 ${ }^{1}$, 井口 善隆 ${ }^{1}$, 鏡 内 肇 ${ }^{1}$, 石井庄一郎 ${ }^{2}$, 美馬 孝至 ${ }^{1}$

【目的】顎変形症に対する治療は近年の歯科矯正, 口腔外科の発展によりその必要性が広く一般にも認識され るようになり，そのニーズが高まってきている。今回われわれは過去 12 年で, NTT 西日本大阪病院歯科口腔 外科にて手術を行った 225 例について, 今後の治療成績の向上を図るため臨床統計的に検討したのでその概要 を報告する。【方法】対象は 1996 年から 2007 年までの 12 年間に当科で手術を施行した顎変形症患者 225 名で ある。検討項目は（1）年度別手術症例数（2）手術時年䶕および性別分布（3）臨床診断別症例数 (4) 術式別 症例数，また下顎枝矢状分割術における（5）固定法別症例数（6）固定期間（7）入院期間（8）骨片移動量と した。【成績】1996 年から 2007 年までの 12 年間に当科で施行した外科的矯正手術症例数は 225 例で年間平均 手術数は 18.75 例であった。性別は男性 50 例（22.2\%）女性 175 例（77.8\%）で男女比は $1: 3.5$ であった。手 術時年歯令は 14 歳から 47 歳にわたり，手術時平均年齢は 25.7 歳であった。臨床診断別症例数では下顎前突が $80.2 \%$ と症例のほとんどを占めた。手術術式は下顎枝矢状分割術が 189 例と最も多く, 内 10 例はオトガイ形 成術を同時施行した。その他は下顎枝矢状分割術，下顎枝垂直骨きり術併用が 4 例，下顎枝垂直骨きり術が 5 例，上下顎骨きり術が 4 例，オトガイ形成術単独が 6 例，上顎皮質骨骨きり術が 4 例などであった。下顎枝矢 状分割術固定方法の 95\%はプレート固定であり，5\%はスクリュー固定であった。また平均出血量は $280.1 \mathrm{~g}$, 平均手術時間は 199.4 分, 平均骨片移動量は $6.81 \mathrm{~mm}$, 平均固定期間は 12.6 日間, 平均入院日数は 17.2 日間で あった。【結論】今回我々は, 1996 年から 2007 年までの外科的矯正施行症例に対し検討し報告する。

\section{$\mathrm{PA}-1-4$ 当科における 22 年間の顎矯正手術の臨床統計的観察}

1 東北大学病院付属歯科医療センター 顎顔面外科

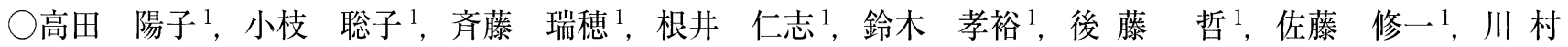
仁 1

【目的】顎変形症に対する顎矯正手術は現在, 多くの施設で行われており, 口腔外科における重要な一分野と なっている。そこで今回われわれは，当科における過去 22 年間の顎矯正手術の実態を明らかにする目的で臨 床統計的観察を行った。【方法】1985 年 1 月〜 2006 年 12 月までの過去 22 年間に顎変形症と診断し, 当科で 手術を施行した手術患者数, 性別, 手術時年齢, 術式, 手術時間, 出血量, 輸血の有無について臨床統計的検 討を行った。【成績】この期間に施行された顎矯正手術症例は1257例で, 男性 358 名, 女性 893 名であった（男 女比は $1: 2.5$ と女性が多かった)。手術時年齢は 10 歳から 61 歳まで広範囲におよび，平均は 23.7 歳であった。 手術術式では，上下顎骨骨切術が560 例 $(44.6 \%)$ と最も多く，次いで下顎骨骨切術単独（オトガイ形成術を 含む）が 511 例 $(40.6 \%)$ ，上顎骨骨切術単独が 45 例 $(3.6 \%)$ ，その他・不明は 141 例（11.2\%）であった。最 も多かった上下顎骨骨切術での平均手術時間は 239.3 分, 出血量は $317.8 \mathrm{~g}$ であった。輸血症例は 6 例で, その うち貯血式自己血輸血が 4 例, 同種血輸血は 2 例であった。【結論】当科では複合手術の割合が多く, 今後よ り多様化した症例への対応が求められるものと考えられる。 


\section{$\mathrm{PA}-1-5$ 当科における過去 30 年間の顎変形症患者の臨床統計}

${ }^{1}$ 札幌医科大学医学部 口腔外科学講座, ${ }^{2}$ 医療法人社団北斗会中央矯正歯科クリニック

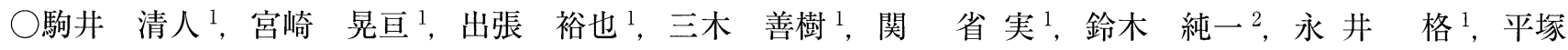
博義 1

【目的】過去 30 年間に顎矯正手術を行った顎変形症患者の経時的变化を知るために臨床統計的検討を行った。 【方法】 1977 年 4 月から 2006 年 3 月までの 30 年間を 10 年毎に 3 期に分類し， 1977 〜 1986 年までを第 1 期, 1987 ～ 1996 年までを第 2 期， 1997 ～ 2006 年までを第 3 期とし，性別，年齢，顎態パターン，術式などにつ いて調査し，比較検討を行った。【成績】総患者数は 666 例で，男女比は $1: 2.5$ であった。年齢は 13 〜 52 歳 (平均 23.2 歳) で, $10 \cdot 20$ 代の患者が 580 例 $(87.0 \%), 30$ 代以降が 86 例（13.0\%）であった。顎態パターン は下顎前突症が最も多く 297 例 $(44.6 \%)$ ，ついで下顎前突症＋顔面非対称が 168 例 $(25.2 \%)$, 下顎前突症 + 開咬が 93 例（14.0\%）の順であった。術式では下顎枝矢状分割術（SSRO）が 559 例（83.9\%）と圧倒的に多く， ついで Le fort I 上顎骨切り術と SSROを併用した上下㖽同時移動術 26 例（3.9\%）, 下顎枝垂直骨切り術 （IVRO） 22 例（3.3\%）であった。各期の比較では，第 1 期が 74 例，第 2 期 316 例，第 3 期 276 例で，男女比 はそれぞれ $1: 2.1,1: 2.6,1: 2.5$ で, 女性の割合に増加が見られた。平均年齢はそれぞれ, 21.5 歳, 22.4 歳, 24.4 歳で年齢の上昇傾向が見られた。顎態パターンは, 3 期とも下顎前突症が最も多く, その傾向に変化はな かった。術式では 3 期とも SSRO が圧倒的に多かったが，第 2 期では上下顎同時移動術が増加し，さらに第 3 期ではこれにIVRO, SSRO とIVROの併用，仮骨延長術も加わり，術式も多彩となってきた。【結論】近年 では顎矯正手術を受ける年齢層が広がり, それに伴い平均年齢も上昇してきた。また，術式の進歩に伴い種々 の顎態に対し，機能のみならず審美性をも考慮した手術が増加する傾向が認められた。

\section{$\mathrm{PA}-2-1$ 顎矯正手術における術後腫張の経時的変化の評価}

1 東京歯科大学 口腔外科学講座

○神 尾 崇 ${ }^{1}$, 与謝野 明 ${ }^{1}$, 笠原 清弘 ${ }^{1}$, 片 倉 朗 ${ }^{1}$, 高木多加志 ${ }^{1}$, 柴原 孝彦 ${ }^{1}$

【目的】顎矯正手術を行うにあたり，顔貌変化の予測は患者へのインフォームドコンセントなどを行う上で重 要であり，術後の腫張の程度や持続期間は患者にとって関心事の一つであると言える。しかし術後腫張に対す る定量的な評価手法は確立されていないため, その予測は半ば経験に基づいたものにとどまっていると考え る。術後腫張の評価には様々な方法が検討されているが, 我々は顔面用非接触三次元形状計測装置を用い定量 的な評価を試みた。また術後腫張と関連性が高いと考えられる因子につき検討を行った。【方法】本研究の主 旨について同意を得られた，当科に於いて䫁矯正手術を施術した顎変形症患者を対象とした。術後腫張の形態 評価には，非接触型三次元形状計測装置 SURFLACER VMH-300F（株式会社ユニスン）を用いて計測を行い, その三次元的形態変化および経時的変化につき評価を行った。術後 12 か月には腫張は消退していると考え, 12 か月時の顎顔面軟組織を基準とし, 術後 1 か月，3 3 月，6 6 か月での評価を行った。術後腫張に関連する因 子として手術時間, 出血量, 血液検査データ, 骨片移動量などについて検討を行った。【成績】1）形態変化： 術後 1 か月と 3 か月の比較では, 煩部下顎下縁にかけての変化が顕著であったが, 術後 6 か月と 12 か月では, その変化は少なかった。2）腫張に関連する因子：出血量, 手術時間, 骨片の移動量で有意な差を認めた。【結 論】術後の腫張には出血量や骨片の移動量が関与すると考えられ，術後腫張の程度や期間の予測に利用できる 可能性が示唆された。 


\section{$\mathrm{PA}-2-2$ 上下顎移動術に伴う鼻唇部形態の検討}

${ }^{1}$ 東京医科歯科大学医歯学総合研究科 顎口胿外科学分野, ${ }^{2}$ 東京医科歯科大学医歯学総合研究科 高齢者歯科学分野, ${ }^{3}$ 国立国際医療セ ンター 歯科口胿外科

○国森健太郎 ${ }^{1,2}$, 丸 岡 豊 ${ }^{1,3}$, 樺沢 勇司 ${ }^{1}$, 佐 藤 昌 ${ }^{1}$, 佐藤百合子 ${ }^{1}$, 盛島 聖子 ${ }^{1}$, 樋口 佑輔 ${ }^{1}$, 小 村 健 ${ }^{1}$

【目的】上顎骨を前方移動すると中顔面の陷凹は改善されるが，鼻翼幅の増大，鼻尖の上向きなどの好ましく ない変化も起こる。術式を検討する上で軟組織の形態変化を正確に予測することを目的として自験例を分析し た。【方法】上下顎移動術を行った患者 42 名（男性 22 名, 女性 20 名）を術前と術後 6 か月の側面頭部 X 線 規格写真と顔面写真を用いて上顎骨移動量, 鼻尖点, 鼻下点, 上唇, 鼻背角, 鼻底角, 鼻唇角, 口蓋平面傾斜 度, 鼻翼幅径を計測し，上顎骨の移動量，回転量で検討した。【成績】上顎骨の前方移動量が増すほど鼻尖は 前方に0〜2 mm (平均 $2.1 \mathrm{~mm}$ )，上方に0〜3 mm（平均 $1.1 \mathrm{~mm}$ ）移動した。鼻下点は前方に $0 \sim 4 \mathrm{~mm}$ (平 均 $2.6 \mathrm{~mm}$ ) 移動した。上唇は水平方向の変位量に幅があり (平均 $2 \mathrm{~mm}$ 前方), 下方に $0 \sim 2 \mathrm{~mm}$ (平均 $1.6 \mathrm{~mm}$ ) 移動し, 鼻下点から上唇の距離は増加した。前方移動量が増すほど, 鼻背角はわずかに大きくなり鼻底角は減 少し鼻唇角は増加した。鼻翼幅は術前に比べて 4 〜 10\%増加した。上顎骨の上方移動量が増すほど，わずか に鼻尖点, 鼻下点, 上唇は前上方移動する傾向を示し, 鼻背角はわずかに大きくなり鼻底角や鼻唇角は減少し た。口蓋平面傾斜度の大きい群は, 前方移動量が増すに従って鼻下点, 上唇ともに前方移動量が小さくなりか つ下方移動量が大きくなった。【結論】軟組織の変化は上顎骨の水平方向移動量に強く影響され，また上顎骨 の垂直方向移動量に対しても少なからず影響を受けていた。上頕骨の移動量に対する軟組織形態の反応に個人 差があり, alar base cinch suture やANS 削合などの手術手技の要因も考えられ, 軟組織形態変化の予測は傾 向が認められるものの幅のあるものとなった。上顎骨の前方移動量が大きい場合では鼻尖は前方移動するが, 鼻唇角が増大し鼻尖形態が鈍角になることで鼻の高さが低くみえる印象を受けると思われた。

\section{PA-2-3 下頡前突症患者における非対称性と下顎歯槽部傾斜度との相関性}

${ }^{1}$ 奥羽大学歯学部 成長発育歯学講座 歯科矯正学分野, ${ }^{2}$ 奥羽大学大学院歯学研究科 顎顔面口腔矯正学専攻 $\bigcirc$ 松山 仁昭 ${ }^{1}$, 黑田 栄子 ${ }^{1}$, 吉 永 聡 $^{2}$, 福井 和徳 ${ }^{1}$, 水室 利彦 $^{1}$

【目的】本研究は，下顎前突症患者における非対称性要因と下顎歯槽部の傾斜度の相関性を知る目的で行った。 【方法】対象には, 奥羽大学歯学部附属病院において非対称性下顎前突症と診断され, 片側性クロスバイトを 呈している症例の中から資料の整っている 12 症例（男性 3 名, 女性 9 名, 初診時平均年齢 23 歳 1 か月, 平均 $\mathrm{ANB}=-2.5)$ を選択した。対照は, 骨格性下顎前突症と診断され, 非対称が認められない症例の中から資料 の整っている 8 症例（男性 2 名, 女性 6 名, 初診時平均年齢 21 歳 4 か月, 平均 $\mathrm{ANB}=-4.7$ ）とした。下顎 口腔模型の三次元画像化に非接触型三次元計測装置（VIVID910 KONICA MINOLTA 社製）を，解析に Rapidform 2006（INUS Technology 社製）を用いた。下顎第一大臼歯，および下顎犬歯における唇側歯頸線 の最深部から歯槽部に引いた接線が基準平面（下顎左側中切歯舌側歯頸線の最深部および第一大臼歯舌側歯頸 線の最深部を通る平面）となす角を下顎歯槽部傾斜角とし，偏位側および非偏位側についてそれぞれ計測し た。偏位側と非偏位側の下顎歯槽部傾斜角の間で unpaired t-test, 下顎歯槽部傾斜角と初診時の頭部 X 線規 格写真分析結果との間で相関分析を行った。【成績】非対称性下顎前突症群では, 偏位側と非偏位側の下顎歯 槽部傾斜角で，第一大臼歯部において有意な差が認められた。非対称性下顎前突症群のオトガイ偏位量と非偏 位側下顎犬歯歯槽部傾斜角に相関が認められた。正中線から非偏位側下顎角（Ago）までの距離と非偏位側の 下顎第一大臼歯歯槽部傾斜角に相関が認められた。【結論】下顎の非対称性は, 非偏位側の下䫟歯槽部の形態 に影響を与える可能性が示唆された。 
PA-2-4＼cjkstart偏位を伴う骨格性下顎前突症患者における外科的矯正治療後の正貌軟組織変化 一手術法の違いによる術後変化の検討一

${ }^{1}$ 新潟大学大学院医歯学総合研究科 歯科矯正学分野, ${ }^{2}$ 新潟大学大学院医歯学総合研究科 組織再建口腔外科分野, ${ }^{3}$ 新潟大学大学院医 歯学総合研究科 顎顔面口腔外科分野

$\bigcirc$ 竹 村 史 $^{1}$, 森田 修一 ${ }^{1}$, 八巻 正樹 ${ }^{1}$, 齋 藤 功 ${ }^{1}$, 齊 藤 力 $^{2}$, 高木 律男 ${ }^{3}$

【目的】従来, 外科的矯正治療に伴う軟組織側貌の変化についての報告は数多く見られるが, 正貌の変化や顔 面非対称症例の術前後における改善度についての報告は少ない。また, 術後の正貌変化について施術法の違い による軟組織変化を比較したものも散見されるだけである。そこで今回, 下顎単独手術を施行した症例と上下 顎移動術を施行した症例を対象に，正貌規格写真を用いて手術前後における正貌軟組織形態変化について検討 した。【方法】研究対象は新潟大学医歯学総合病院矯正科診療室において偏位を伴う骨格性下顎前突症と診断 され，外科的矯正治療を施行された女性 36 名とした。資料は手術直前および術後 4 か月以上経過時に同一条 件で撮影された正貌規格写真とし，軟組織上の任意の点からの水平距離・角度について計測を行った。【成績 および結論】正面セファログラム上で手術前後における Me 偏位量は Two-jaw 群でより有意に改善されるこ とが示され，偏位を有する顎変形症症例では，下顎単独の手術より上下顎移動術を選択した方が偏位を改善す る上でより有利であると考えられた。また，鼻部幅径は従来の報告でも認められるように One-jaw 群では変 化が生じなかったが, Two-jaw 群では増加する傾向が認められた。口唇幅径の術後変化については One-jaw 群では減少, Two-jaw 群では増加を示し, 口唇周囲軟組織の変化にも手術法の違いが関倸していると考えら れた。しかし, 両群とも口唇幅径は偏位側で減少, 非偏位側では増加して術後に対称性の向上が図られてい た。また，口裂傾斜度については 2 群ともに有意な改善を示していた。さらに下顔面輪郭の左右差に関する角 度計測項目は有意な変化を示し，下顔面輪郭の非対称性は術後に改善する傾向を認めたが，これらの角度変化 には 2 群間で有意差を認めず，口裂傾斜や下顔面輪郭の改善は下顎骨の移動による影響が大きいことが示唆さ れた。

\section{PA-3-1 表面領域重心点基準法（Surface-based method）による顎顔面正中矢状面決定法 について 一硬・軟両組織の相違一}

${ }^{1}$ 北海道医療大学歯学部 口胿外科学第 1 講座, ${ }^{2}$ 北海道医療大学歯学部 歯科矯正学講座, ${ }^{3}$ 北海道医療大学 個体差医療科学センター $\bigcirc$ 辻 祥 之 ${ }^{1}$, 上 地 潤 ${ }^{2}$, 武田 成浩 ${ }^{1}$, 北所 弘行 ${ }^{3}$, 溝 口 $\quad$ 到 $^{2}$, 柴田 考典 ${ }^{1}$

【目的】当大学では，顎顔面変形症症例に対して X 線 CT からの顔面骨格情報と三次元スキャナからの歯列形 態情報を融合したシミュレーションモデルを生成し, 三次元的にサージカルトリートメントゴールを設定して いる。われわれの方法では, CT 画像情報から得られた顎顔面モデルにおいて, 適切な正中矢状面を決定し, 直交座標系を構築することが重要となる。従来の報告の多くは顎顔面の両側に存在する解剖学的ランドマーク を基準とする計測点基準法（Landmark-based method）などが用いられていた。しかし，この方法は客観性 にそしく，再現性が低い欠点がある。そこで，われわれはこれら短所の改善を目指し，表面領域重心点基準法 （Surface-based method）を採用した。本研究では，顎顔面正中矢状面の決定に，骨格表面を基準とした場合 と軟組織表面を基準とした場合とを比較し, 検討を行った。【方法】本研究は, 顎変形症患者を対象とし, エックス線 CT から得た骨格情報から, 片側骨格表面の眼窝上縁・煩骨領域を CAD ソフトウェア上で選択・ 複製し，任意の矢状面を基準に鏡像を作成し，ICP（逐次最近点）法を用いて反対側眼窩上縁・煩骨領域へ適

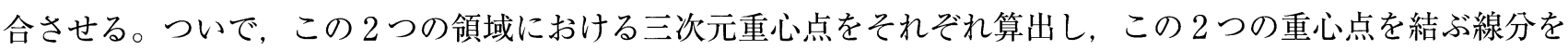
作製，この線分の中点を原点とし求めた線分を法線とする平面を算出し，顎顔面正中矢状面（H）とした。こ れとエックス線 CT から得た軟組織情報から体表面を基準に，同様の方法で顎顔面正中矢状面（S）を求め, それらを比較した。【成績】顎顔面がほほ対称な被験者では，顎顔面正中矢状面（H）と顎顔面正中矢状面 (S) とは，ほほ一致していた。【結論】顎顔面変形症患者における正中矢状面の決定法として，表面領域重心点基 準法が優れているとともに，診断的応用も示唆された。 
$\mathrm{PA}-3-2$ 顔面軟組織形態の対称性に関する研究

\section{一口腔外科医・矯正歯科医・患者の主観的評価の比較—}

\section{${ }^{1}$ 東京歯科大学歯学部 口腔外科学講座}

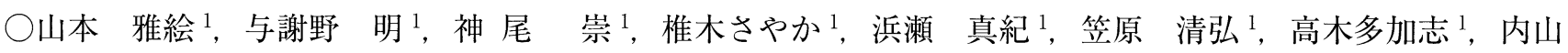
健志 ${ }^{1}$, 高野 伸夫 ${ }^{1}$, 柴原 孝彦 ${ }^{1}$

【目的】顎変形症患者の治療に際して, 顔面軟組織形態の対称性を評価する場合, 口腔外科医・矯正歯科医の 主観的評価が中心であり明確な診断基準は存在しない。今回，患者本人の顔面軟組織形態の対称性について患 者自身の主観的評価と歯科医師による評価が一致しているのか, 治療を担当する歯科医師相互における主観的 評価に違いはないのかの点に着眼し本研究をおこなった。【方法】対象は, 顎変形症の治療を希望して東京歯 科大学千葉病院口腔外科を受診した患者 25 人である。患者の顔面軟組織形態の対称性の評価は, 歯科医師に よる主観的評価には正貌写真を用い, 西山らの基準を参考に Grade $0 \sim 3 の 4$ 段階として評価した。評価者は 口腔外科医 13 名, 矯正歯科医 4 名とした。患者本人の主観的評価には, 自身の正面顔貌とアンケート調査に より対称性に対する自己評価を行った。患者と歯科医師との評価結果は統計学的に比較した。【成績】患者の 主観的評価において Grade 0 とした者は 3 名, Grade 1 は 14 名, Grade 2 は 7 名, Grade 3 は 1 名であった。 これに対し口腔外科医の評価が一致したのが Grade 0 は 46\%, Grade 1 は 36\%, Grade 2 は $23 \%$, Grade 3 は38\%。矯正歯科医は Grade 0 は $58 \%$, Grade 1 は $30 \%$, Grade 2 は $21 \%$, Grade 3 は $0 \%$ あった。統計 解析では kendall の一致係数において口腔外科医間については 0.527 , 矯正歯科医間については 0.606 。口腔外

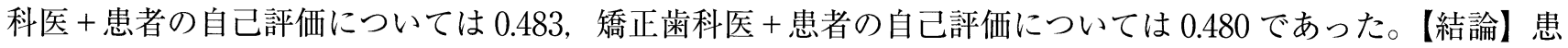
者自身の主観的評価が Grade 2 3の場合，歯科医師のほうがその患者に対し低いGrade に評価している傾 向がある。統計解析では対称性の主観的評価は三者間において有意に一致しているが，歯科医師間のほうが主 観的評価に統制がとれていると考えられる。

\section{$\mathrm{PA}-3-3$ 顔面非対称症例の初診時における硬組織と軟組織の比較検討}

1 福岡歯科大学 成長発達歯学講座 矯正歯科学分野, 2 福岡歯科大学 口腔・顎顔面外科学講座 口腔外科学分野 ○久 永 豊 ${ }^{1}$, 泉 喜和子 ${ }^{2}$, 宇治 寿隆 ${ }^{2}$, 池邊 哲郎 ${ }^{2}$, 石川 博之 ${ }^{1}$

【目的】顔面非対称症例の治療計画を立案する際, 正貌における硬・軟組織形態の関係を把握することは審美 的, 機能的咬合を確立する上で重要である。これまでに正面頭部 X 線規格写真を用いた硬組織形態や正貌規 格写真を用いた軟組織形態の検討は数多くなされてきた。しかしながら, 両者の関連について検討したものは 少ない。そこで今回，顔面非対称症例の初診時における硬・軟組織形態の関係について比較検討した。【方法】 資料は過去 10 年間に福岡歯科大学医科歯科総合病院に来院した患者のうち, 顔面非対称と診断され, 正面頭 部 X 線規格写真分析で顔面正中に対し下顎骨の側方偏位量が $3.0 \mathrm{~mm}$ 以上の成人女性 40 名（平均年齢 21 歳 8 か月）で, その初診時の正面頭部 X 線規格写真と正貌規格写真を用いた。なお, 被験者の抽出にあたっては 先天異常を有す患者は除いた。まず，40名の正面頭部 X 線規格写真と正貌規格写真の角度および距離計測を 行った。その後, 硬・軟組織形態の計測結果の比較を行った。【成績】硬組織の偏位に対する軟組織の偏位は, 上顎骨を含む中顔面部や顎角部では関連が弱く，オトガイ正中部では関連が強い傾向がみられた。また，硬組 織における咬合平面傾斜と軟組織における口裂線の傾斜に関連がみられた。【結論】顔面非対称症例では, 硬 組織および軟組織の偏位の関連性が顔面各部で異なることが示唆された。 
$\mathrm{PA}-3-4$ 外科的矯正治療が構音に与える影響について

${ }^{1}$ 琉球大学医学部 高次機能医科学講座 顎顔面口腔機能再建学分野

$\bigcirc$ 比 嘉 努 ${ }^{1}$, 天願 俊泉 ${ }^{1}$, 新坦 敬一 ${ }^{1}$, 新 崎 章 $^{1}$, 砂 川 元 $^{1}$

【目的】顎変形症患者では, 形態的異常による咬合の異常と異常顎運動による口腔機能障害が認められる。こ れら口腔機能障害のなかには，咀嚼障害や言語障害などがある。今回われわれは，言語障害のなかでも高頻度 に認められる構音障害に着目し，当科において外科的矯正治療を行った顎変形症患者を対象に，術前後の構音 障害における変化について比較検討を行ったので報告する。【方法】対象は，当科において外科的矯正治療を 行った患者とし, 方法は当科専任の言語聴覚士における 3 音節復唱検査, 文章検査により構音検査を行った結 果を使用した。【結果】外科的矯正治療患者の術前の構音障害の特徴は, 従来報告されてきたものと一致して おり, 術後に改善傾向を認めたものが多かった。【結論】音声は, 歯や歯周組織, 舌, 口唇などの相互作用に より呼気流の通路を遮断したり広げたり狭めたりすることにより構音されるが, 不正咬合者は咬合に形態異常 を伴うために，機能的に代償していることが多いとされている。一般的に，下顎前突症では上下顎歯列間に常 時舌を露出しているため, 構音操作に要する舌の正常な運動機能の学習が妨げられ, 舌尖歯音・舌尖歯茎音に 構音障害が認められるとの報告もある。また，開咬症の場合は舌で開咬部分を閉塞する習慣があるため，舌尖 歯音・舌尖歯茥音の歪みを来しやすく，しばしば舌を前歯部に押し当てて嚥下をする異常習癖を伴うこともみ られる。これらの構音障害の多くは，外科的矯正治療によって特に構音訓練を行わなくても自然に消失する傾 向があると報告されている。以上のことをふまえ, 当科で行った外科的矯正治療患者の術前後の 3 音節復唱検 査, 文章検査などの構音検査の比較検討を行った結果, 外科的矯正治療患者の術前の構音障害の特徴は従来報 告されてきたものと一致しており，術後に改善傾向を認めたものが多かった。

\section{PA-3-5 Acoustic Characteristics of Speech for Pre and Post Orthognathic Surgery Patients}

${ }^{1}$ Department of Oral \& Maxillofacial surgery, School of Dentistry, \& Research Institute of Speech Science, Chonbuk National University, JeonJu, Korea

OKil-Jung Jeong ${ }^{1}$, Kyeng-Sook Jeon ${ }^{1}$, Jin-A Baek ${ }^{1}$, Hyo-Keun Shin ${ }^{1}$

【Purpose】 The purpose of this study was to demonstrate the characteristics of speech for pre and post orthognathic surgery patients as well as to provide clinicians with valuable data based on the acoustic analysis of the speech of orthognathic patients. 【Method】 In order to analyze the nasality of word containing Korean consonants, Korean consonants and frequency and intensity of the fricative /s-/, Nasometer and Computerized Speech Lab. were used. 【Result】 The results were as follows: 1. The nasality of post orthognathic surgery patients decreased in spontaneous speech. There was a significant difference in the nasality for all words between pre and post orthognatic surgery patients. 2. The nasality of each Korean consonant phoneme of post orthognathic surgery patients decreased. There was also a significant difference of the nasality for each Korean consonant phoneme between pre and post orthognatic surgery patients. 3 . The decreased nasality for Korean consonant phonemes showed in plosives, affricatives, fricatives, liquids, and nasals after surgery. But the significant difference showed only in plosives and fricatives. 4. Frequency and intensity for the fricative /s/ of post orthognathic patients increased. 


\title{
PA-4-1＼cjkstart開咬を伴う骨格性下顎前突症 3 例の長期術後経過からみた安定性の検討
}

\author{
1 東京医科歯科大学大学院医歯学総合研究科 顎顔面矯正学分野

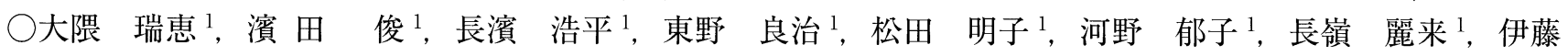 \\ 公一 ${ }^{1}$, 川元 龍夫 ${ }^{1}$, 森山 啓司 ${ }^{1}$
}

【目的】近年外科的矯正治療は進歩し，術後の後戻りに関しては良好な結果を得ることが多い。しかし，開咬 を伴う症例の術後の安定を図ることは難しいとされている。今回, 長期術後経過が得られた開咬を伴う骨格性 下顎前突症 3 例を報告し, 術後の安定性に影響を与える要因を検討した。【症例】症例 1 : 初診時年齢 25 歳 3 か月の男性。上顎右側第二小臼歯を抜歯し術前矯正治療を行い, 上顎骨 Le Fort I ・下顎骨体部分切除術・才 トガイ形成術を施行した。術後 10 年が経過し咬合は安定している。症例 $2:$ 初診時年齢 21 歳 4 か月の男性。 上顎両側第二小臼歯を抜歯し術前矯正治療を行い, 下顎枝矢状分割術を施行した。術後 10 年が経過し, 上下 顎前歯部の空隙・前歯部に切端咬合が認められた。症例 3 : 初診時年齢 22 歳 11 か月の女性。上顎両側第一小 其歯を抜歯し術前矯正治療を行い, 下顎枝矢状分割術を施行した。術後 16 年が経過し, 下顎前歯部の空隙・ 前歯部に開咬が認められた。【考察およびまとめ】症例 1：上下顎移動術を行い，上顎骨は前方移動を行った ことにより口胿内容積が確保され舌の影響を極力抑えられたこと, 下顎骨体部分切除術を行ったことが術後の 安定性に寄与したと考えられる。症例 2：下顎前歯歯軸の唇側傾斜が後戻りの大きな要因であった。これは, 術後の舌の影響が大きかったことが考えられる。症例 $3:$ 術後 10 年経過時では咬合は安定していたが，その 後，抗うつ薬を服用した既往があり，薬物服用の影響が後戻りに関与した可能性がある。外科的矯正治療患者 の術後 10 年以上の長期にわたる報告は少なく, 今回 3 症例の報告から開咬症例における長期的な後戻りに関 与する要因を挙げることができた。現在，当分野では術後 5 年ごとに定期観察を行っているが，今後は咬合や 顎態の評価以外にも軟組織の評価や薬物服用等の全身状態の把握が必要であると思われる。

\section{PA４－２ＩSW を用いて術後矯正治療を行った骨格性下顎前突症患者の治療期間と術後安定 性に関する検討}

${ }^{1}$ 横浜市立大学附属市民総合医療センター 歯科. 口腔外科 - 矯正歯科, ${ }^{2}$ 東京医科歯科大学大学院 医歯学総合研究科 咬合機能矯正学 分野

尾崎 周作 ${ }^{1,2}$, 富田 大介 ${ }^{1,2}$, 岡本 喜之 ${ }^{2}$, 福山 英治 ${ }^{1}$, 大 村 $\quad$ 進 $^{2}$, 相馬 邦道 ${ }^{1}$

【目的】顎矯正手術後の骨格性の後戻りは，顎骨の移動量や移動方向，手術方法や術後咬合管理の期間など多 くの因子との関連が考えられている。近年, 外科的矯正治療を求める患者の多くは, 咬合機能の改善と同時に 審美性の改善を強く希望する傾向にあるだけでなく, 患者自身を取り巻く社会的環境の多様性から, 手術時期 や入院，治療期間の短縮にまで配虑を望むことが少なくない。このような患者の訴えに対して我々は, 術後早 期の咀嚼機能の回復を目的に, 改良・超弾性型 Ti-Ni 合金角型ワイヤー（以下 ISW）を用いた術後矯正治療を 行っている。しかしながら，弾性に富む ISW で十分な術後の安定性が維持できるかについてはいまだ不明な 点が多い。そこで今回 ISW を用い，短期に保定を開始した症例における顎顔面形態と咬合の術後安定性に関 して評価を行ったので報告する。【症例】対象は，当科にて上下顎同時移動術による外科的矯正治療を施術し た骨格性下顎前突症患者で, 手術直後より ISW を用いて 6 か月以内に保定開始した 5 症例とした。安定性の 検討には, 手術直後, 術後約 3 か月, 保定開始時抢よび保定期間中に抢ける側面頭部 X 線規格写真を用いて, 顎顔面形態の術後変化について検討した。【考察㧍よびまとめ】術後 6 か月以内に全症例を通して, 軽度の PNS の下方への後戻りおよび上顎大臼歯の挺出が認められる傾向にあったが, それ以降は顕著な骨格性の後 戻りは認められなかった。ISW を用いた術後矯正治療は術後早期に咀嚼機能の回復を達成し, 比較的安定し た術後経過と治療期間の短縮にも寄与している可能性が示唆された。 
PA-4-3 下䯪枝矢状分割法における骨片固定法の検討 一骨縫合固定法と Miniplate 固定法の比較—

${ }^{1}$ 福岡歯科大学 口胿顎顔面外科学講座

○寺川 紘子 ${ }^{1}$, 泉 喜和子 ${ }^{1}$, 村 山 敦 ${ }^{1}$, 宇治 寿隆 ${ }^{1}$, 池邊 哲郎 ${ }^{1}$, 大 関 悟 ${ }^{1}$

【目的】現在当科では下顎枝矢状分割法（以下 SSRO と示す）の骨片固定法として骨縫合固定法と Miniplate 固定法を行っている。今回, SSRO にて後方移動した症例について固定法の違いによる術後安定性について比 較検討したので報告する。【方法】対象は骨格性下顎前突症の診断下に, 2003 年〜 2006 年に当科でSSROを 施行し, 術後半年以上経過しており資料が整った 30 例（骨縫合固定症例 15 例・Miniplate 固定症例 15 例）で, 後方移動量 $4 \mathrm{~mm}$ 以上とした。性別は男性 13 名，女性 17 名で，平均年齢は 23.13 歳（17～37 歳）であった。 また術後安定性については, 術直後, 術後 6 か月の側面頭部 X 線規格写真より, SNB, Ramus Angle, L1MP, overjet, overbite を計測した。さらに, 術前後の顎関節症状, 知覚異常の有無, 手術時間, 出血量等に ついて検討した。【成績】術後安定性については, SNB, Ramus Angle, L1-MP, overjet, overbite ともに術 直後と術後 $6 \mathrm{M}$ に有意差は認めなかった。また, 知覚異常の有無は骨縫合法で $75 \%$, Miniplate 固定法で $76 \%$ となった。手術時間は骨縫合法で 2 時間 13 分, Miniplate 固定法で 2 時間 9 分となり大きな差はなかった。 出血量は骨縫合法 $150 \mathrm{ml}$, Miniplate 固定法 $250 \mathrm{ml}$ となった。さらに, 固定期間は骨縫合法で 13 日, Miniplate 固定法で 5 日であった。【結論】後戻り, 在院日数等を含めて骨縫合法と Miniplate 固定法を比較検討す る予定である。

\section{$\mathrm{PA}-4-4$ 術後治療中断期間中に著明な後戻りを来した 3 症例}

${ }^{1}$ 東京歯科大学水道橋病院 口腔外科, 口腔健康臨床科学講座 口胿外科学分野, ${ }^{2}$ 東京歯科大学水道橋病院矯正歯科, 口胿健康臨床科学 講座 歯科矯正学分野

$\bigcirc_{\text {渡辺 }}$ 玲子 ${ }^{1}$, 柿 澤 卓 $^{1}$, 高野 正行 $^{1}$, 高崎 義人 ${ }^{1}$, 横山 葉子 ${ }^{1}$, 瀬田 修一 $^{1}$, 桑山 真寧 ${ }^{1}$, 未石 研二 ${ }^{2}$, 海老原 環 ${ }^{2}$

【目的】近年，口腔外科領域では顎変形症に対する治療が増加している。これらに対して外科的矯正治療が応 用されているが，治療には長期間を有し，良い結果を得るためには患者自身の協力が不可欠である。とくに十 分な術後治療が行われないと術後に咬合の安定を欠き, 後戻りの可能性も大きくなると考元られる。今回われ われは，適切な術前矯正を行った上で上下顎同時移動術を行ったが，その後患者が治療を中断した期間に著明 な後戻りを起こし，再び手術を行って回復した 3 症例を経験したのでその概要を報告する。【症例 1】17歳, 男性。下顎前突感を主訴に来院。平成 5 年 12 月より矯正治療開始。初回手術：平成 7 年 8 月。顎間固定を除 去した後に未来院となり，平成 10 年 1 月に反対咬合を呈し再来院した。下顎左右第一小臼菌を抜歯したが改 善ないため, 矯正治療を再開し追加手術を計画した。2 回目手術：平成 13 年 1 月に下顎前方歯槽部骨切り術 施行。【症例 2】19 歳, 男性。下顎前突感を主訴に来院。平成 12 年 2 月より矯正治療開始。初回手術 : 平成 14 年 4 月。約 3 週間後に顎間固定を除去したが，それ以降未来院となった。平成 15 年 4 月に再来院したが明 らかな骨格性の下顎前突症を呈していたため, 矯正治療再開。2 回目手術：平成 15 年 9 月に下顎枝矢状分割 術施行。【症例 3】 20 歳, 女性。咬合の不調和を主訴に来院。平成 15 年 5 月より矯正治療開始。初回手術 : 平 成 17 年 6 月。約 3 週間後に顮間固定を除去したが，その後約 1 か月半の間未来院となり，この間に著明な後 戻りを呈した。2 回目手術 : 平成 18 年 6 月に下顎枝矢状分割術施行。【考察抢よびまとめ】 3 例ともに術後は 経過良好である。外科的矯正治療では適切な術前矯正と手術が行われていても後戻りを引き起こすことがあ り，これらを予防するためには術後の定期的な咬合管理と観察，またそれに対する患者の認識が非常に重要で ある。 


\title{
$\mathrm{PB}-1-1$ 象牙質脱灰基質によるラビット膝関節全層欠損部修復への有用性の検討
}

\author{
1 愛知学院大学歯学部 歯科矯正学講座 \\ ○八木橋敬介 ${ }^{1}$, 宮 澤 健 $^{1}$, 後藤 滋巳 ${ }^{1}$
}

【目的】骨欠損部への補填・再建に用いられる移植材料として骨の生着が良好かつ安全であることから新鮮自 家骨が最も多く使用されている。しかし, 新鮮自家骨移植材は, 骨採取における健常組織の外科的侵襲が大き く, 患者の骨組織の供給量と形態に限界がある。それら欠点を補う骨補填材として, 移植材料採取のための二 次的な侵襲が無く，骨誘導能を有する BMP を含む便宜抜去された歯や智歯の健全歯象牙質を利用することを 目的とした。今回, 我々は象牙質中に含まれる有機質である牛歯脱灰歯基質 (Demineralized dentin Matrix： 以下 DDM とする）をラビット膝関節全層欠損部に埋植し，DDM による骨・軟骨修復能について検討した。 【方法】ウシ下顎前歯抜去歯より作製した DDM を, $2.5 \mathrm{~kg}$ 雄ラビットの大腿骨膝蓋窩に作製した欠損部（直径 $5 \mathrm{~mm}$ 高さ $10 \mathrm{~mm}$ ) に埋植した。DDM50mg 埋植群, $100 \mathrm{mg}$ 埋植群と対照群にわけ, 1 週, 3 週, 6 週, 9 週 にて屠殺後, 新生骨, 新生軟骨の形成状況を肉眼的所見による評価と X 線学的評価, 組織学的評価にて検討 した。【成績】対照群において，3 週では欠損部深部海綿骨と表層部軟骨様組織の修復はほとんど認められず, 6 週では海綿骨の修復とともに周辺軟骨から薄層の軟骨層の修復がみられたが表層中心部軟骨欠損は修復され ていなかった。DDM100mg 埋植群では 3 週において著明な海綿骨修復がみられ，6週においては表層部修復 軟骨で完全に覆われていた。【結論】DDMは，ラビット膝関節全層欠損部修復において骨補填材として極め て有用である可能性が示唆された。

\section{PB-1-2 圧迫骨短縮術におけるサル上顎骨の治癒過程に関する組織形態学的検討}

1 大阪歯科大学 口腔外科学第二講座

$\bigcirc$ 砂田 典子 ${ }^{1}$, 中嶋 正博 ${ }^{1}$, 覚道 健治 ${ }^{1}$

【目的】近年，成人の骨格性上顎歯槽前突症に対し，上顎前歯歯槽部（以下前方骨片とする）にブロック単位 で corticotomy を施行し, 同時埋入したテンポラリー・アンカレッジ・デバイスを併用して上顎前歯部を一塊 として後上方に移動させる圧迫骨短縮術が試みられている。しかし基礎的な検討はなされていないため，咬合 様式や上顎形態が人に近いサルを用いて骨移動時の組織学的変化を観察した。【方法】アカゲザルおよびカニ クイザル 4 頭に対し圧迫骨短縮術を施行した。術後 1 週後より，左右煩側および口蓋側よりスプリングコイル （各 $200 \mathrm{~g}$, 計 $800 \mathrm{~g}$ ）を用いて上顎前歯歯槽部を一塊として後上方に牽引した。移動経過時および移動終了後 における骨切り部の変化について，HE 染色および共焦点レーザー顕微鏡を用いて観察した。蛍光ラベリング 剤としてカルセインおよびアリザリンレッドを用い, 屠殺 2 週間前にカルセイン，屠殺 5 日前にアリザリン レッドを腹腔内投与した。【成績】 HE 所見では皮質骨骨切り（corticotomy）部には炎症細胞の出現が少なく， 破骨細胞と骨芽細胞の存在を認めた。共焦点レーザー顕微鏡所見では, 皮質骨骨切り (corticotomy) 部に沿っ てカルセインとアリザリンレッドの沈着を認めた。また，アリザリンレッドの沈着は皮質骨骨切り（corticotomy）部の遠心側に高度にみられ，移動側（皮質骨切り部の遠心側）に骨新生が観察された。【結論】圧迫骨短 縮術では前方骨片に持続的に矯正力をかけるために，治癒過程において骨吸収と骨造成が同時に進行しながら 骨改造が生じていた。このため, 歯および歯髄に影響なく前方骨片の移動が可能で，治療期間の短縮が可能な ことが示唆された。 


\section{$\mathrm{PB}-1-3 \quad$ 顎変形症治療における自家歯牙移植の応用}

1 九州大学大学院歯学研究院 口腔保健推進学講座 咬合再建制御学分野, ${ }^{2}$ 九州大学大学院歯学研究院 口胿顎顔面病態学講座 顎顔面 腫瘍制御学分野

○北原 亨 ${ }^{1}$, 中島 昭彦 ${ }^{1}$, 利谷 幸治 ${ }^{2}$, 白土 雄司 ${ }^{2}$

【目的】顎変形症患者の術前矯正に際し，術中の感染や骨折などを防ぐ目的で，下顎骨切り術であれば下顎第 三大臼歯の抜歯，上下顎骨切り術であれば上顎第三大臼歯を抜歯する症例は少なくない。と同時に，深刻な力 リエスや歯周疾患によって保存不可能な状態の歯牙を有する症例や, 術前矯正による臼歯部の便宜抜歯を余儀 なくされる症例も存在する。埋伏第三大臼歯の即時自家歯牙移植は, 久損部や先天性欠如歯による複雑な矯正 治療上の問題を解決する有効な方法であるが，一方では，歯牙移植後，歯根膜再生獲得までに移植歯の一定期 間の安静が必要であり，炎症性歯根吸収や置換性歯根吸収への対策など，手術を前提とした顎変形症矯正治療 に対して治療を煩雑にする傾向があることも事実である。【方法および成績】症例 $1: 24$ 歳男性, 開咬を伴っ た下顎前突 $\left(\mathrm{SNA} 80.9^{\circ}, \mathrm{SNB} 90.5^{\circ}\right)$ 。上顎左右第二大臼歯および下顎左右第三大臼歯抜歯後, 22 か月の術前矯 正後, 上顎左右第三大臼歯の上顎第二大臼歯部への移植 8 か月後, 上下顎骨切り術を施行した。症例 $2: 19$ 歳 男性，下顎左右第二乳臼歯が残存しており下顎左右第二小眠歯が先天的欠如していた。上顎の劣成長を伴った 下顎前突 $\left(\mathrm{SNA} 76.8^{\circ}, \mathrm{SNB} 87.3^{\circ}\right)$ 。上顎左側第三大臼歯の下顎左側第二乳臼歯抜歯部へ移植 8 か月後，上下顎 骨切り術を施行した。症例 $3: 22$ 歳男性, 下顎左方偏位を伴った下顎前突（SNA82.2, $\mathrm{SNB}^{\circ}$. $4^{\circ}$ )。両側下顎 枝矢状分割術施行 8 か月後スクリュー除去時に，上顎左側埋伏第三大臼歯の下顎左側第二大臼歯欠損部へ移植 した。【結論】手術のための抜去歯の自家移植を術前術後矯正治療中に行い，良好な結果を得た。健康な移植 歯と十分な広さを有する健康な受容部を準備するとともに, 術前術後矯正治療期間の効率化を図ることが肝要 と考えられた。

\section{PB-1-4＼cjkstart自家移植と外科矯正治療を行った骨格性下顎前突患者の術後長期経過例}

${ }^{1}$ 東京歯科大学 歯科矯正学講座, ${ }^{2}$ 東京歯科大学 口脉外科学講座, ${ }^{3}$ 新潟大学大学院医歯学総合研究科 䫟顔面再建学講座 組織再建 口腔外科学分野

○茂木 悦子 ${ }^{1}$, 高根 ユミ ${ }^{1}$, 徳永 恵理 ${ }^{1}$, 山口 秀晴 ${ }^{1}$, 高野 伸夫 ${ }^{2}$, 柴原 孝彦 ${ }^{2}$, 齋 藤 力 $^{3}$

【目的】下顎第二大臼歯の垴失を伴う骨格性下顎前突者に対し，反対側下顎第三大臼歯の自家移植と外科矯正 治療を行い, 治療後 6 年を経過して移植歯, 咬合ともに安定している症例を報告する。【症例】初診時の概要： 初診時年齢 42 歳, 女性。下顎前突を主訴として来院。矯正治療経験はない。全身的には軽度の貧血がある事 以外は特記事項はない。上顎左側第二大臼歯, 下顎右側第二大臼歯は既に抜去されている。オーバーバイト $-3 \mathrm{~mm}$ ，オーバージェット-1.5mm，AngleIII 級である。上下顎とも叢生はほとんど見られない。パノラマ エックス線写真では且歯部に軽度の歯槽骨吸収像が認められる。側面頭部 X 線規格写真分析では SNA78 $\mathrm{SNB} 80^{\circ}, \mathrm{ANB}-2^{\circ}$, 下顎角 $142^{\circ}$ で，特に垂直的な下顎過成長を呈す。前歯部開咬をともなう骨格性下顎前 突と診断。治療方針：形態的，機能的改善を得るため, 非抜歯にて Saggital splitting Ramus Osteotomyによ る外科的矯正手術とした。右側下顎第二大臼歯部には左側下顎第三大臼歯の自家移植を行うとした。経過：マ ルチブラケット法にてレベリング, 術前矯正開始 5 か月で自家移植を行った。術前矯正 1 年 6 か月, 術後矯正 7 か月で動的治療を終了した。保定では上下顎ともにベッグタイプの可撤式装置を装着した。保定 1 年まで来 院，6 年後リコールにより来院した。この間特に問題はなかったという。現在保定装置は使用していないが移 植歯ならびに咬合状態は良好に保たれている。下顎前歯部舌側に歯肉退縮と歯垢の沈着が認められた。【考察 およびまとめ】骨格性下顎前突は前歯部皮質骨が非薄なための歯肉退縮や保定中の叢生の再発などが見られる 事がある。本症例は歯列, 咬合は安定していたが下顎前歯部舌側の歯槽骨吸収が見られ，今後観察が必要であ る。歯列の安定には移植した最後臼歯が安定していることも要因と考えられた。 


\section{PB-2-1下䫈前歯部歯槽骨切り術に用いるコバルトクロム合金製固定用シーネに関する検} 討

1 京都大学医学部附属病院 歯科口胿外科技工室, ${ }^{2}$ 京都大学大学院医学研究科 感覚運動系外科学講座 口埶外科学分野 $\bigcirc$ 高 木 朗 ${ }^{1}$, 高 橋 克 $^{2}$, 田村 佳代 ${ }^{2}$, 藤村 和磨 ${ }^{2}$, 西田 光男 ${ }^{2}$, 別所 和久 ${ }^{2}$

【目的】下顎前歯部歯槽骨切り術で使用される固定用シーネは離断された骨片を予定位置に導き固定させる上 で重要な役割をもつ。レジンと補強線を用いて製作する従来のものは強度面ではワイヤー結禁時に変形が起こ る可能性をもち, 装着後もシーネの形状は患者に違和感を与え, 発音障害の一因となっている。加えて下顎舌 側に伸ばされた床部分は術後, 形態が変化した顎堤粘膜を圧迫し虚血を引き起こす危険性をもつ。更に口腔内 清掃の妨げとなることから, 衛生的見地からも悪影響を与える要因を有していた。今回われわれは上記の従来 型レジン製固定シーネのもつ問題を解決するために，コバルトクロム合金製固定シーネの設計，製作工程等に 関し検討を行う。【方法】使用材料をレジンから廉価なコバルトクロム合金へと変更するにあたり，レジンに てパターンを製作，マスターモデル上にて試適を行い作業模型の精度を確認した後鋳造に移行する工程を追加 した。次いで計測用に製作した樹脂モデル上にてレジン製，金属製両者にワイヤー結紮を施した後，移動値誤 差の計測を行い実用に耐えうる機能性，操作性を有するか検証を行った。その後下顎前歯部歯槽骨切り術を施 行した患者に使用し, 臨床的評価を加えることとする。【成績】形態的に厚みはレジン製のものと比較して 3 分の 1 以下となり, 床縁は歯牙マージン部より下方約 2 ミリまでとなった。機能的には結禁時の変形は大幅に 改善されたことに加え, 発音機能, 清掃性が著しく向上した。粘膜面に接触させないため虚血の危険性も軽減 させることができた。【結論】コバルトクロム合金によって製作した固定シーネはレジン製のものと比較し機 能的に優れ，術者の操作性や患者の使用感のうえでも良好な結果が得ることが可能である。

\section{PB-2-2 歯列，顎骨および顔面形状デー夕を統合した 3 次元シミュレーションシステムに 関する考察}

1 佐賀市立国民健康保険三瀬診療所歯科, ${ }^{2}$ 佐賀大学医学部 歯科口胿外科学講座

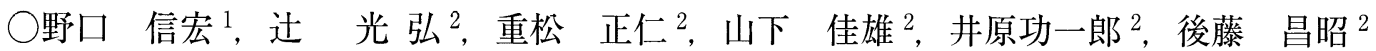

【目的】歯列, 顎骨, 顔面形状データを頭部 X 線規格写真（以下，セファログラム）を使用して統合する顎矯 正手術 3 次元シミュレーションシステムの開発をおこなってきた。このシステムは, 歯列の 3 次元的な動きか ら下顎骨骨片の動き, 顔面形状の変化を分析するものである。今回は, 本システムの特徴と有用性, 問題点に ついて考察した。【方法】歯および顔面の形状データはレーザースキャナーより得られる。下顎骨形状は標準 的なテンプレートのデータをセファロ計測に合わせて変形する。各オブジェクトをセファログラムの射影に適 合するようにシミュレーションソフトウエアを使って位置づける。このコンピュータシミュレーションモデル を用いて骨切りの歯列および骨片の移動, 顔面形態の変化を分析する。【特徵と有用性】本システムの特徴は, CT データを用いずに歯, 下顎骨, 顔面の 3 次元シミュレーションモデルが得られることであり, 下顎骨骨切 りと骨片移動のシミュレーションを行うことができる。顔面形態の分析, 顎関節への影響, 歯列移動の分析, および顔面の精密なレーザースキャンが繰り返し行えることから，顔面形態の経時的な変化を分析するのに役 立つ。【問題点】データの統合に用いた projection matching 法の原理は単純であるが, 現状ではオブジェク トの位置あわせの操作が煩雑である。また，下顎骨形態の再現は近似的である。【考察】近年の 3D-CTの普及 によって，3 次元での頭部計測や骨切りシミュレーションは比較的容易になってきた。空間距離，空間角度の 標準值も定められようとしている。一方，セファログラムを使って異なるデー夕を統合した本システムは骨切 りデザインと骨片移動の簡便なシミュレーションや，経時的な顔面形態変化の分析に有用であると思われる。 また, 3D-CTによる 3 次元計測と, 従来より蓄積されてきたセファロ計測值の比較にも本システムは有効で ある。 


\section{PB-2-3 術後に炎症症状を呈し生体吸収性プレートを除去した下顎骨骨折の 1 例}

${ }^{1}$ 東京医科歯科大学大学院医歯学総合研究科 顎顔面外科学分野

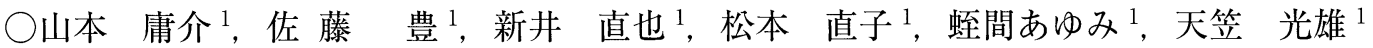

【目的】生体吸収性プレートは近年, 骨折や顎変形症の治療に広く用いられているが, 分解吸収することから 除去される機会はほとんどない。今回，下顎骨骨折の固定約 1 年後に生体吸収性プレートを除去する機会を得 たので，成分分析の結果と合わせて報告する。【症例】患者は 18 歳の男性。平成 17 年 3 月オートバイ事故に て下顎正中部の骨折および多数歯破折を生じ，搬送先の某大学病院救命センターにて受傷 5 日後に吸収性プ レートによる観血的整復固定術と顎間固定を施行された。術後約 3 週間後からプレート上の歯肉に腫脹を生じ るも痛みがないために放置していたが，平成 17 年 7 月，紹介により当科に受診した。初診時，下顎前歯部歯 肉に径 $7 \mathrm{~mm}$ 程度の暗赤色の肉芽様の腫脹があり，X 線写真では下顎正中部に吸収性スクリューの孔と考えら れる透過像を認めた。残存する下顎前歯はすべて生活歯であった。投薬にて腫瘤は消失せず，平成 17 年 10 月 に生検を行った結果, 病理組織診断は炎症性肉芽組織であった。その後, 同部に腫瘤が再発し MRI を撮影し たところ，下顎骨正中部唇側に吸収性プレートと思われる像が認められた。これによる炎症反応と考え，平成 18 年 3 月プレート除去術を施行し, 多数の破片を摘出した。骨折部は治癒していた。その後, 同部の再発は 認められない。摘出したプレートを分析したところ平均分子量は $19,000 〜 23,000$ でり，埋入 1 年後の一般 的な分解状態であった。【考察およびまとめ】吸収性プレートによる遅発性異物反応の報告は多いが，本症例 では術後約 3 週間と比較的早期に炎症を生じている。吸収性プレートは機械的強度では金属製プレートに劣る が，骨折部の治癒が認められたことから，骨折部の固定，安静には概ね良好であったと思われる。しかし，術 後約 3 週間頃には肉芽様隆起を生じていたことから適応については慎重な検討を要する。

\section{PB-2-4 下顎枝矢状分割術における Fixsorb MX（Box 型プレート）の有用性}

\section{${ }^{1}$ 長野赤十字病院 口腔外科}

○清 水 武 ${ }^{1}$, 横林 敏夫 ${ }^{1}$

【目的】ポリ乳酸性（PLLA）ミニプレートは, 生体内吸収性であるため除去手術を必要としないなどの利点 を有し，下顎枝矢状分割術の固定にも広く用いられている。今回われわれは，下顎枝矢状分割術にFixsorbMX（ボックス型プレート）を使用し，その有用性を検討した。【材料ならび方法】夕キロン社（株）より 2000 年 4 月に発売されたボックス型ミニプレート（Fixsorb-MX: BX4 型プレート）は, 従来型のストレート 型プレート L 型プレートに比べ強度が改良され，より高い固定力が得られる。対象症例は，2005 年 3 月から 2006 年 1 月までに両側下顎枝矢状分割術を施行し, ボックス型ミニプレートによる Rigid fixation を行った下 顎前突患者 10 名（男性 2 名, 女性 8 名）である。術後の臨床所見から合併症の有無を評価し, 側面頭部 X 線 規格写真を用いて術後 1 年間の下顎骨の安定性について検討した。【結果】骨接合部の炎症所見はなく，プレー 卜破折を疑う所見も認められなかった。側面頭部 X 線規格写真では, 術後に有意な後戻り傾向は認められな かった。【結論】Fixsorb-MX（ボックス型プレート）は，下顎枝矢状分割術の Rigid fixationにおいて優れた 有用性が認められた。 
PB - 3-1下顈前突症患者における下顎枝矢状分割術後の咬合状態に関する検討 一咬合感圧测定シートを用いた術後長期経過観察について—

${ }^{1}$ 札幌医科大学医学部 口腔外科学講座, ${ }^{2}$ 医療法人社団北斗会中央矯正歯科クリニック

$\bigcirc$ 宮崎 晃亘 ${ }^{1}$, 永 井 格 $^{1}$, 出張 裕也 $^{1}$, 駒井 清人 ${ }^{1}$, 畠山 考身 ${ }^{1}$, 関 省 実 $^{1}$, 三未 善樹 ${ }^{1}$, 鈴木 純一 ${ }^{2}$, 平塚 博義 ${ }^{1}$

【目的】顎矯正手術を施行した患者の咬合機能に関する検討は術後 1 年以内の報告が多く，術後長期にわたる 報告例は少ない。演者らは以前に下顎前突症患者の術前から術後 1 年における咬合力の経時的変化について検 討し, 歯列全体の咬合力は術後 1 年で術前值を上回るものの, 正常咬合者と比較し有意に低いことを報告し た。今回, 術後 3 年までの長期経過観察例における歯列全体の咬合力と, さらに歯種別（大曰歯部，小四歯部， 犬歯部, 前歯部) の咬合状態の経時的変化について検討したので報告する。【方法】対象は当科で下顎枝矢状 分割術を施行した開咬や非対称を伴わない骨格性下顎前突症患者 20 名（男性 7 名, 女性 13 名）で，個性正常 咬合を有する 20 名（男性 7 名，女性 13 名）を対照とした。咬合力の測定は，咬合感圧測定シート（Dental Prescale $^{\circledR}, 30 \mathrm{H}-\mathrm{W}$ タイプ，富士写真フィルム社製）を用い，術前および術後 $1,2,3$ 年に咬合状態の記録を行っ た。得られた資料はオクルーザーFPD-703（富士写真フィルム社製）で測定した。咬合状態として歯列全体 と歯種別に咬合力, 咬合接触面積, 咬合圧の 3 項目の経時的変化について対照群と比較検討した。【成績】歯 列全体の咬合力は経時的に増加し, 術後 3 年では正常咬合者のレベルに達する改善を示した。一方で, 歯種別 の咬合力は, 大臼歯部, 小臼歯部において術後 2 年でほぼ正常咬合者のレベルに達する改善を示したが, 犬歯 部および前歯部では術後 3 年を経ても依然として低值を示し，正常咬合者のレベルには達していなかった。 【結論】術後 3 年目における歯列全体の咬合力の増加は, 主として大臼歯部, 小臼歯部の咬合力の増加による ものと考えられた。

\section{PB-3-2 オトガイ形成術術後の知覚障害に関する臨床的研究}

1 東京歯科大学 口腔外科学講座, 2 東京歯科大学水道橋病院 口腔外科

○浜瀬 真紀 ${ }^{1}$, 山本 雅絵 ${ }^{1}$, 与謝野 明 ${ }^{1}$, 神 尾 崇 ${ }^{1}$, 椎木さやか ${ }^{1}$, 笠原 清弘 ${ }^{1}$, 高崎 義人 ${ }^{2}$, 高木 多加志 ${ }^{1}$, 内山 健志 ${ }^{1}$, 高野 伸夫 $^{1}$, 柴原 孝彦 $^{1}$

【目的】顎変形症に対する外科的矯正治療において, 下顎枝矢状分割術（以下 SSRO）や Le Fort I 型骨切り術 と SSROによる上下顎同時移動術を行うことで咬合の改善は図れるものの，機能的，審美的な改善を図るた めにオトガイ形成術が必要であることも多い。従来より SSRO 術後の知覚障害に関する報告は多いものの, オトガイ形成術術後の知覚障害についての詳細な報告は認められない。そこで今回私たちは, オトガイ形成術 後の知覚障害の発現の仕方やその経過について検討を行った。【方法】対象は当講座においてオトガイ形成術 を行った患者 109 人のうち, SSROもしくはLe Fort I 型骨切り術と SSRO による上下顎同時移動術の術後に プレート，スクリュー除去と同時にオトガイ形成術を行った症例 44 人 88 側を対象とした。なお，これらはオ トガイ形成術の術前に知覚障害のないものを対象とした。知覚検査の方法は, 患者の自覚症状を聴取するとと もにSW 知覚テスターによる触圧覚閾值検査（以下 SW test）を行った。また, 知覚検査は手術前, 手術 1 , 4, 12 週後に行った。【成績】知覚障害の発現率については, 何らかの自覚症状の訴えのあったものは手術 1 週後, 4 週後, 12 週後においてそれぞれ $82.95 \%, 21.3 \%, 9.3 \%$ あった。また SW testでは手術 1 週後, 4 週後, 12 週後においてそれぞれ $55.68 \%, 21.9 \%, 10.96 \%$ あった。また移動距離との比較を行ったところ，手術 1 週後に SW testで知覚障害を認めたもののうちの $57.8 \%$ $7 \mathrm{~mm}$ 以上の移動であった。【結論】オトガイ形成 術術後の知覚障害の発現率は, 手術 1 週後では SW test に比べると自覚症状の方が高かったものの, 手術 4 週後，12 週後ではあまり差はなかった。また，移動距離の大きいと知覚障害が発現しやすい傾向にあった。 


\title{
$\mathrm{PB}-3-3$ 顎矯正手術前後で睡眠呼吸障害の改善がみられた一例
}

\author{
'東京菌科大学 オーラルメデイシン・ロ脭外科学講座, 2 東京菌科大学市川総合病院 耳鼻㽠喉科

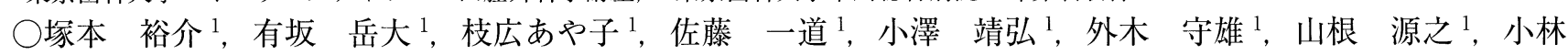 \\ 小百合 ${ }^{2}$, 吉田 正弘 $^{2}$, 大櫛 哲史 ${ }^{2}$, 中島 庸也 $^{2}$
}

【目的】顎顔面形態は閉塞型睡眠時無呼吸症候群（OSAHS）の病態に関与することが多くの報告によって示さ れている。また顎矯正手術は顎骨の形態のみでなく, 鼻腔や咽頭といった上気道の形態・機能的な変化を起こ すことに論を待たない。今回，顎矯正手術にあたり睡眠呼吸状態に配慮し，良好な結果を得た症例を経験した ので報告する。【症例】患者は初診時年齢 22 歳の女性。叢生を伴うアングル 2 級の開咬症例に対し, 小臼歯非 抜歯で歯列矯正による動的治療を終了していた。しかし上顎の突出感が気になるという審美的な主訴にて来院 した。診断の後, Le Fort I 型骨切り術による上顎骨体の上方移動とオトガイ形成術による前方移動を計画し た。既往として通年性アレルギー性鼻炎があり鼻閉を認めた。また頭部 X 線規格写真からも咽頭気道の狭窄 傾向を認め, 日中の軽度傾眠傾向もみられた。そこで当院耳鼻咽喉科との併診の上, 鼻胿に関しては鼻内手術 も併せて行うこととし上顎骨体の上方移動に配慮した。またオトガイ形成術は前方移動によって, 舌骨上筋群 を牽引し咽頭気道の開大を図れるよう工夫した。術後, 顔貌に関しては良好なプロファイルを獲得することが でき，鼻閉は改善されていた。また術後 1 年の睡眠呼吸障害の評価では Apnea Hypopnea Index, Lowest $\mathrm{SpO} 2$ の改善がみられ, 特に臥位での著明な改善を認めた。【考察およびまとめ】本症例を経験し, 咬合の改 善を目的とした顎矯正手術においても，睡眠呼吸障害に十分配慮する必要性を改めて認識した。

\section{PB-3-4＼cjkstart骨格性下顎前突症患者の顎矯正手術前後における咽頭気道の変化について 一睡眠時無呼吸症候群患者との比較—}

1 札幌医科大学医学部 口腔外科学講座

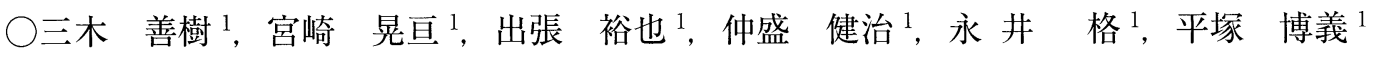

【目的】骨格性下顎前突症患者において，顎矯正手術後に咽頭気道の狭窄をきたした場合，睡眠呼吸障害を引 き起こす可能性がある。一方, 近年, 睡眠時無呼吸症候群が注目され, 顎顔面形態と咽頭気道の関連について さまざまな検討がなされている。そこで本研究では, 骨格性下顎前突症患者で上下顎同時移動術を行った群と 下顎後退術を単独で行った群の手術前後の咽頭気道の変化を, 睡眠時無呼吸症候群患者の咽頭気道と比較し, 術式による違いについて検討した。【方法】札幌医科大学附属病院歯科口腔外科で顎矯正手術を施行した骨格 性下顎前突症患者で上下顎同時移動術を行った 10 名（2-jaw 群），下顎後退術を単独で行った 10 名（1-jaw 群） と睡眠時無呼吸症候群患者 10 名 (SAS 群) を対象に，手術前後の側面頭部 X 線規格写真を用い，顎顔面形態 と咽頭気道の関連性について比較検討した。【成績】上下顎間関係は各群共に改善したが，2-jaw 群の上咽頭 腔は増加し, 下咽頭腔は減少した。1-jaw 群では中咽頭腔, 下咽頭腔共に減少した。また, 術後の咽頭気道の 大きさは2-jaw 群，1-jaw 群の順で小さくなるが, SAS 群よりは大きかった。【結論】2-jaw 群は1-jaw 群に比 ベて咽頭気道の狭窄は少ないことがわかった。また，1-jaw 群による咽頭気道の狭窄が直ちに呼吸障害に繋が ることはなかったが, 術式を検討する際には考慮する必要があると考えられた。 
PB-3-5 Management of Inadvertent Condyle Fracture during the Sagittal Split Ramus Osteotomy: Reports of Cases

${ }^{1}$ Department of Oral and Maxillofacial Surgery, School of Dentistry, Kyungpook National University, Daegu, Republic of Korea OJae- wook Lee ${ }^{1}$, Sang-Han Lee ${ }^{1}$, Chin-Su Kim${ }^{1}$, Hyun-Jung Jang ${ }^{1}$, Dae-Keun Kwon ${ }^{1}$

Condyle fracture is one of rare side effects occurring in the process of Orthgnathic surgery. Fractures more frequently occur during the process of Split Sagittal Ramus Osteotomy in an unintended direction and during the set-back of mandible where condyle neck gets thinner in the process of eliminating interferences. Generally, rigid fixation using wire and plate is recommended, but application of Physical therapy after Closed reduction with continuous follow up is also an efficient treatment as well. 5 patients out of 214 SSRO patients between 2003-2006 at our department experienced unwanted condyle fracture. To these 5 patients, 3 weeks long inter-maxillary fixation and physical therapy after the reduction was performed instead of rigid fixation. Author, achieving favorable healing effect without any complications by performing closed reduction, and physical therapy to the condyle fractured patients, reports such cases on successfully healed patients with academic discussions.

\section{PB-4-1＼cjkstart多数歯欠損を伴った骨格性下顎前突症の 1 例}

${ }^{1}$ 九州歯科大学 口胫㖽顔面外科学講座 病態制御学分野, ${ }^{2}$ 九州菌科大学 機能育成学講座 顎口胿機能燆正学分野 ○吉 岡 泉 ${ }^{1}$, 冨永 和宏 ${ }^{1}$, 古田 功彦 ${ }^{1}$, 福田 仁一 ${ }^{1}$, 藤田 邦彦 ${ }^{2}$

【目的】多数歯欠損を伴う顎変形症は，術前後の矯正治療が困難であることなどから，その治療に苦慮する。 今回われわれは多数歯欠損を伴った骨格性下顎前突症の 1 例を経験し, 咬合の安定と良好な顔貌が得られたの で報告する。【症例】初診時年齢 27 歳, 男性。主訴：咀嚼障害と下顎の前突感。現病歴：13 歳頃から下顎の 前突感を認めた。26歳頃までに䶚蝕のため多数歯を抜去されたが, 補緅治療は行われなかった。現症 : 顔貌 所見；正貌は左右対称で，側貌では下顎の前突が認められた。口腔内所見：15，25，26，34，35，36，45，46 が欠損し, 咬合時には 17 と 47 のみが接触し, 27 と 37 は著しく挺出していた。 X 線所見 : 側面頭部 X 線規格 写真分析では SNA は $81.0^{\circ}, \mathrm{SNB}$ は $87.5^{\circ}$ であった。診断：骨格性下顎前突症。治療経過：術前矯正治療では skeletal anchorage system（SAS）を利用し，27 と 37 の圧下を行った。術前矯正治療終了時は歯列全部位で すれ違い咬合を呈したため, スプリントを用いて咬合高径を維持し, 顎関節障害などが認められないことを確 認した後に，両側下顎枝矢状分割術を行った。【考察およびまとめ】多数歯欠損を伴う骨格性下顎前突症の 1 例を経験した。本症例では, 術前矯正治療にSAS を利用することは有用で, 術後に咬合の安定と良好な顔貌 が得られた。 


\section{PB-4-2 上下顎前歯部歯槽骨切りを選択した上頢前突の 1 症例}

${ }^{1}$ 日本歯科大学附属病院 顎変形症診療センター

○小林さくら子 ${ }^{1}$, 宮下 $\quad$ 涉 $^{1}$, 安藤 文人 ${ }^{1}$, 宇 塚 聡 ${ }^{1}$, 藤城 建樹 ${ }^{1}$, 小林隆太郎 ${ }^{1}$

【目的】上下顎歯列弓の狭窄を伴い，著しい上下顎前歯部の突出により口唇閉鎖が困難な上顎前突の症例にお いて，上下顎前歯部歯槽骨切りを行い，良好な結果が得られたので報告する。【症例】初診時年齢 22 歳 9 か月 の女性。上顎前突と口唇閉鎖不全を主訴に来院した。精査の結果，上下顎歯列弓の狭窄とガミースマイルを伴 う上顎前突症と診断された。正貌においては，鼻下点からオトガイ下点までの距離は長く，側貌においては， 鼻唇角は鋭角でオトガイ部は後退し, 口元の突出が著明であった。下顎骨においては下顎下縁平面角が大き く, 時計廻りに回転しており, 下顎前歯の唇側傾斜が認められた。上顎歯列は $\mathrm{V}$ 字型を呈し, アングル I 級, overbite $+1.0 \mathrm{~mm}$, overjet $+3.0 \mathrm{~mm}$ であった。治療目標は口唇閉鎖が容易になること, 咀嚼機能の回復, 側 貌の改善とした。治療方針としては，上顎右側第三大臼歯，下顎左側第三大臼歯，上下顎左右側第一小臼歯を 抜歯し，上下顎前歯部歯槽骨切りを併用する外科的矯正治療を行うこととした。動的治療期間 2 年 5 か月（術 前知正 1 年 4 か月, 術後矯正 1 年 1 か月）を要し, 現在保定 2 年経過し安定している。【考察およびまとめ】 本症例において，治療方針として上下顎左右側第一小臼歯を抜歯し，矯正治療のみで行う方針も立案したが， 治療目標の口元の著しい突出を改善するためには，矯正治療だけでは十分な効果が得られないと判断し，患者 とインフォームドコンセントを交わした結果, 上下顎前歯部歯槽骨切りを選択した。この場合, 術後確実に骨 を癒合させるために，形成骨片の主たる血液供給路を十分に確保し，固定を確実に行うなど，術式には十分な 配慮が必要となる。また，ガミースマイルの悪化は避けなければならないことから，手術方法の選択は慎重に 行わなければならなかった。治療後口唇閉鎖は容易になり, 上顎前歯部は圧下され満足のいく結果が得られ た。

\section{$\mathrm{PB}-4-3$ 片側中下顔面の陥凹感を伴う顔面非対称の 1 治験例}

1 神戸大学大学院医学系研究科 器官治療医学講座 口腔外科学分野, ${ }^{2}$ 神戸大学医学部付属病院 歯科口腔外科矯正歯科診療班 $\bigcirc$ 内田 玲子 ${ }^{2}$, 立石 千鶴 ${ }^{2}$, 関本 真由 ${ }^{2}$, 西 周 子 ${ }^{1}$, 古土井春吾 ${ }^{1}$, 横 尾 聡 ${ }^{1}$, 古森 孝英 ${ }^{1}$

【目的】顔面の著しい左右非対称感が認められた症例において上下顎移動術を行い咬合および顔貌の審美性の 改善を図った症例を経験したので報告する。【症例】初診時年齢 32 歳 11 か月の女性で顔貌の非対称感を主訴 に来科した。正貌で下顎の右方偏位, 左側の中下顔面にかけて陥凹感が認められ, 上顎歯列の正中が人中に対 して 5.0mm, 下顎歯列が $3.0 \mathrm{~mm}$ 右方偏位していた。側貌は convex type であった。口腔内所見は, overjet - 1.0mm, overbite $0 \mathrm{~mm}$ で，右側が上下顎第二小囦歯以外で交叉咬合を呈していた。また上顎右側犬歯の埋 伏と下顎左側側切歯の先天欠如が認められた。側面頭部 X 線規格写真分析では, ANB + 4.5 $5^{\circ}$ Wits 3.7 , FMA $36.5^{\circ}$ の High angle case であった。1 年 6 か月間の術前矯正治療の後に, 三次元実体モデルを用いて骨 切り部位, 方法, 移動量の最終決定を行い, 上顎骨には Le Fort I 型骨切り術（左側へ $5.5 \mathrm{~mm}$ 移動, 左側臼 歯部 $2.0 \mathrm{~mm}$ 圧下と右側臼歯部 $2.0 \mathrm{~mm}$ 挺出）を施行し, 左側中顔面部の陥凹感の改善を困った。また, 右側に 腸骨移植を行い吸収性ミニプレートで固定した。下顎骨は，右側は下顎枝矢状分割術にて前方移動を，左側は 下顎骨垂直骨切り術にて後方移動を行い右方偏位の改善を困った。また，右側のみ吸収性ミニプレートにて固 定した。12 か月間の術後矯正治療の後, 上下顎にBegg type retainer を用いて保定観察を行った。【考察およ びまとめ】左側中下顔面の陥凹感が認められた著しい左右非対称症例に対して上顎骨を左側に移動させ上下顎 移動術を行ったところ，正貌の非対称感は改善し満足する結果を得ることができた。現在保定観察中であるが 安定した咬合状態を維持しており，今後も注意深く経過観察を継続する予定である。 
PB-4-4＼cjkstart晚期成長による後戻りに対して Le Fort I 型骨切り手術を施行した再治療症例

${ }^{1}$ ふかか矯正歯科, ${ }^{2}$ 北里大学医学部 形成外科学講座, ${ }^{3}$ 東京医科歯科大学大学院医歯学総合研究科 顎顔面外科学

○府川 俊彦 ${ }^{1}$, 山崎 安晴 ${ }^{2}$, 下社あゆみ ${ }^{1}$, 中久木康一 ${ }^{3}$

【目的】今回我々は, 晚期成長による後戻り症例に対して Le Fort I 型骨切り手術を適用して良好な結果が得 られたので報告する。【症例】初診時 8 歳 6 か月の女子で, 受け口と乱杭歯を主訴として来院した。側貌は convex type で上下顎前突様の顔貌をしていた。上顎左中切歯の萌出スペースが不足し，埋伏していた。大臼 歯の咬合関係は Angle class III, overjet $-0.5 \mathrm{~mm}$ ， overbite $-0.5 \mathrm{~mm}$ と反対咬合を呈していた。嚥下時には 舌突出癖が認められた。セファログラム分析より上顎前歯の唇側傾斜と下顎の過成長が認められた。チン キャップで下顎成長抑制を行うとともに，マルチブラケット装置で反対咬合と上顎前歯部の叢生を改善し，筋 機能療法を行いながら保定装置で永久歯列完成まで経過観察を行った。11 歳 10 か月時に上下顎左右第 1 小臼 歯を抜歯し, 叢生と上下顎前突を改善し, 13 歳 6 か月時に保定治療に移行した。約 2 年の経過観察後は通院 が途絶えたが，19歳 1 か月時に咬合の後戻りと下顎の突出に対して顔貌の改善も含めた外科手術による治療 を希望して再来した。口腔内所見としては下顎歯列に空隙があり，切端咬合を呈していた。正貌は丸顔，側貌 では中顔面部がやや後退していた。上顎第 3 大臼歯を抜歯し，6か月の術前矯正治療後に Le Fort I 型骨切り 手術と鼻修正手術を施行して上顎を約 $5 \mathrm{~mm}$ 前方移動, 術後矯正 4 か月で動的治療を終了し, 現在保定観察中 である。【考察およびまとめ】本症例は晚期成長により後戻りを生じ, 咬合の改善と下顎の突出を主訴として 再来したが, 正・側貌の評価に基づき, Le Fort I 型骨切り手術に鼻修正手術を併用した外科矯正治療を行っ た。その結果, 良好な咬合が獲得され，顔貌も改善された。

\section{PB-4-5上下顎同時移動手術を要した著しい骨格性下頡前突症・顔面非対称症例の 2 治験 例}

${ }^{1}$ 東京歯科大学 口胿健康臨床科学講座 歯科矯正学分野, ${ }^{2}$ 東京歯科大学 口沿健康臨床科学講座 口埶外科学分野

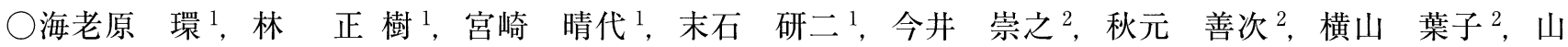
満 $^{2}$, 高野 正行 ${ }^{2}$

【目的】骨格性下顎前突症 - 顔面非対称症例においては前後的・左右的顎間関係の不調和に伴い, その不調和 を補うような歯軸傾斜（Dental compensation）がしばしば認められる。このような歯軸傾斜を術前矯正治療 において改善し, 顎矯正手術において十分な前後的・左右的な移動量を確保する事が術後の顔貌および咬合の 改善と長期的安定性においては重要である。今回我々は著しい骨格性下顎前突症・顔面非対称症例を術前矯正 治療において煩舌歯軸傾斜を積極的に改善し，上下顎同時移動手術を施行することで良好な顔貌および咬合の 改善が得られた 2 症例を経験したので報告する。【症例】症例 1 : 初診時年齢 40 歳 2 か月の女性で主訴は顔面 非対称，下顎前突ならびに叢生と反対咬合であった。下顎の左方偏位による顔面非対称と下顎前突症を認め た。症例 2 : 初診時年齢 20 歳 9 か月男性で顔面の非対称，下顎前突抒よび咬合改善を主訴に来院した。下顎 の左方偏位による顔面非対称と下顎前突症を認めた。両症例とも骨格性下顎前突症・顔面非対称と診断し, 上 下顎同時移動手術による外科的矯正治療を行うことで決定した。【結果】両症例とも下顎前突および顔面非対 称は改善し, 個性正常咬合が確立された。【考察およびまとめ】術前矯正治療では, 歯軸傾斜の改善（decompensation）が顎矯正手術における移動量の確保につながり, 術後の咬合の安定と顔貌の改善には大切である。 重藤らによれば顔面非対称患者では上下顎ともに第一大臼歯は偏位側と非偏位側で頓舌的歯軸に有意差を認 め, 左右的な骨格性の不調和に対する歯牙補償の存在を報告している。顔面非対称患者の治療では，このよう な煩舌的な田歯部の歯軸傾斜の改善が重要である。本症例は術前矯正治療において煩舌的な臼歯部の歯軸傾斜 を.018 ×.025 ステンレススティール 2 ループワイヤーを用い積極的に改善を行った結果, 良好な顔貌と咬合 を獲得できたものと考えられる。 